\title{
Adaptive Capacity of Coupled Ecosystem - Social System in the Community Who Live in the Graviar: A Case Study the population in the areas of Brintik Hill Graveyard Communities in Semarang, Indonesia
}

\author{
Y.Y.F.R.Sunarjan \\ Department of History Faculty of Social Sciences Universitas Negeri Semarang Semarang,Central Java Indonesia \\ Coresponding email: sunarjan@yahoo.co.id
}

\begin{abstract}
I see, there are two system in the world. Social system and ecosystem. There are multidimensional problems.. Individuals, families, groups in the population, in the areas of Brintik Hill Graveyard Communities in Semarang..They live in miserable housing conditions and have bad sanitary and hygienic conditions. Social system have sensitivity and adaptive capacity.The problems are how the two system, coupled ecosystem and social system work in the world..Aims of this research is to investigate the role of selection and adaptation in providing service delivery and in affecting coupled ecosystem- social system out comes. Qualitative methods, phenomenological approach, and naturalistic - paradigm applied in this research. In recent years, there has been a growing interest in ecosystem based adaptation (EBA). EBA addresses the role of environmental services in reducing the vulnerability of natural resource dependent societies in a multisectoral and multiscale approach. They lack the resources to obtain the types of diet, participate in the activities and have the living conditions and amenities which are customary, or at least widely encouraged or approved in the societies to which they belong. Their resources are so seriously below those commanded by the average individual or family that they are, in effect, excluded from the ordinary living patters, customs and activities. Breaking link of the vicious circles of economic and political poverty by using the social values, and community capital of Brintik Hill Grave-yard Communities. Applying of social value, collaboration, community capital and needs for achievement needed for breaking supporting the vicious circles of economic and political poverty. An actual participation in local institutions, their use of services, and information that identifies the welfare level of households and their coping strategies. Interventions may be enhancing their conditions. Government intervention and Non Government Organizations intervention could be used in cutting the vicious circles of economic and political poverty. Adaptive capacity in coupled social system - ecosystem to result a model of survival strategy in historical sociology - ecology.
\end{abstract}

Keywords: adaptive capacity, natural selection, social system sensitivity, social capital, environmental management.

\section{Introduction}

The population in the areas of Brintik Hill Graveyard Communities in Semarang City, that can be said to be in poverty. The poor are underand malnourished. They live in miserable housing conditions and have bad sanitary and hygienic conditions. There are 4 areas of Brintik Hill Graveyard Communities

1. Hillside communities, lower hillside up to hilltop (RT I s/d RT IX), that relatively survive.2.Hillside after hill top (plan for RT X), hilltop and the valleys areas of Brintik Hill Graveyard Communities.3. The community of PKL(Pedagang Kaki Lima) flower seller near the streets and rivers a round of Dominico Savio Middle High School.4. The community of PPJ (Persatuan Pedagang dan Jasa/Union of Traders and Services Community) a round of DR Sutomo streets,Kalisari, Semarang.

\begin{tabular}{|c|c|c|c|c|}
\hline \multicolumn{5}{|c|}{$\begin{array}{c}\text { Table } 1 \\
\text { Number of Poor Hoesehold of The Brintik HiW Gr } \\
\text { Receiving Direet Cas }\end{array}$} \\
\hline $\begin{array}{l}\text { Neighbour } \\
\text { hood } \\
\text { Associative } \\
\text { (RT) }\end{array}$ & $\begin{array}{c}\text { Cemmuaity } \\
\text { Association } \\
\text { (RW) }\end{array}$ & $\begin{array}{c}\text { Poor } \\
\text { Household }\end{array}$ & $\begin{array}{c}\text { Direet } \\
\text { Cush Aid } \\
\text { Houschold }\end{array}$ & $\begin{array}{c}\text { Total } \\
\text { Houschold }\end{array}$ \\
\hline 01 & III & 11 & 4 & 37 \\
\hline 02 & III & 15 & 7 & 25 \\
\hline 03 & III & 18 & 6 & 43 \\
\hline 04 & III & 30 & 13 & 43 \\
\hline 05 & III & 23 & 8 & 31 \\
\hline 06 & III & 22 & 17 & 45 \\
\hline 07 & III & 21 & 6 & 46 \\
\hline 08 & III & 29 & 14 & 43 \\
\hline 09 & III & 27 & II & 40 \\
\hline 10 & III & 22 & 11 & 30 \\
\hline Sum & & 218 & 107 & 377 \\
\hline
\end{tabular}


The problems are why the poor and peripheral people as the graveyard communities become developed and survive. The article aims to investigate the role of adaptive capacity in providing service delivery and in affecting welfare and poverty out comes.

\section{Method}

Why I chose and focused to the populations in the areas of Brintik Hill Graveyard Communities in Semarang, Central Java , the community who live in the graviar?

\begin{abstract}
"It is important that you chose one specific site, this will help to keep things simple and to focus on the issues and areas for improvement. It is important to go into a site with an open mind, and not assuming you already know the solutions for other people's problems. (King Beach \& Flavia Ramos. 2010.)
\end{abstract}

Qualitative methods, phenomenological approach, and naturalistic paradigm applied in this research.

A brief description of select methodological studies on social sciences, and proceed with the results and conclusions of our own work.

Data were collected at the level of the community, the district and the household. At the level of the community, interviews with focus groups of households and with community leaders were held to establish a map of functioning institutions in the community.

Donor relations with local institutions: how can one work with local institutions most effectively? This last theme aims to extract the operational lessons from the previous analyses and to illuminate whether and how donor organizations can invest in social capital by supporting local institutions. A first lesson will relate to the range of local institutions relevant for a specific type of service delivery. (Ms. Gracie M. Ochieng May 1998, Working papers no1 http://www.worldbank.org/socialdevelopment, Washington, DC :The World Bank. Social Development.)

\section{Results \& Discussion}

In recent years, (Locatelli, $2008 \mathrm{~b}$ ) there has been a growing interest in ecosystem based adaptation (EBA). EBA (Locatelli, 2008a) addresses the role of environmental services in reducing the vulnerability of natural resource dependent societies in a multisectoral and multiscale approach. They lack the resources to obtain the types of diet, participate in the activities and have the living conditions and amenities which are customary, or at least widely encouraged or approved in the societies to which they belong.

There are flows of energy, material, and information from and to social system, from and to ecosystem. Social system selected and adapted to ecosystem. Social system and ecosystem had adaptive capacity. They had sensitivities.

Commonly, the peoples who coming in the empty areas of Brintik Hill Graveyard are the peoples which have not places or land. It will use a building or home places. Sum of them are poor people come from several village around Semarang and Central Java.

Advasory capital is effort to adapt sorounding people who life in the graviar. For many parents, children are their economic future. They are an insurance policy, and a savings product. The social norms may also reflect economic interests in a society. The poor want many children simply because it is an economic investment. The Children as financial instruments. All so some time a little baby was rented from the other person. Baby to be used by the women who rented as instrument for her ask the money to the driver on the way.

Community capital is a helpful concept because it takes into consideration both the environment characteristics of the individual people in the community and the forces from the environment. It suggests that a person brings to the situation a set of behaviors, needs, and beliefs that are the result of his or her unique experiences.

Yet it also recognizes that whatever is brought to the situation must be related to the world as that person confronts it. It is in the transactions between the person and the parts of that person's world that the quality of life can be enhanced or damaged. Here in lies the uniqueness of social work. Civic involvement increases social capital because it enhances the amount of personal interaction, increases information on the degree of trust that each individual is worthy of and thus consolidates the overall level of trust (Putnam 2000). At the same time the networks of civic responsibility supply relational goods such as contacts, information and reputation which are of significant 
value. These goods can be conserved only if individuals remain within a framework of community relationships. The spread of civicness appears to reduce the problems of opportunism because when initiatives take place within a context of personal relationships and social networks, there is greater likelihood that agreements will be kept. This is because of the fear that if an agreement is broken the sanction imposed can be the exclusion from the system of individual and collective agreements. Being able to use community goods is thus an important incentive in avoiding defection and putting the relationship of trust at risk. A causal link between social capital and individuals' propensity to co-operation is confirmed by a great deal of empirical evidence among others, Putnam 1996; Narayan and Pritchett 1997;Molinas 1998).It is however far from certain that similar conclusions can be drawn for inter-firm co-operation. Both the modality of collective action and the nature of social capital are partially different for individuals and for firms.

Among the many differences, we note that firms are not subject to the same sanctions as individuals. Many forms of exclusion, such as social ostracism, cannot effectively be applied to organisations. Moreover, many models of collective action are based on the continuity of relationships and a long time horizon, while a large proportion of firms, newer ones, have a short life expectation. It does therefore not seem appropriate to interpret the phenomenon with reference to a framework with an important time scale. The fact that social capital is only part of the explanation of inter-firm co-operation leads us to look for a wider interpretative model. This model uses two further explicative variables: institutional initiative and the accumula-tion of past co-operation experience.

The basic of our model gives an important role to government institutions, mainly local but also central, in pro-moting and sustaining directly and indirectly cooperative initi-atives. It if people act trustfully, they tend to cooperate and invite cooperation in return. However, to promote large-scale economic exchange are necesary education and collaboration. Food is basic to welfare, a necessity for survival. Where malnutrition is widespread and famine a threat the point is very evident, while the need for food is often taken for granted in modern societies.

The interaction between formal and informal networks accounts for the readiness with which discussions can move back and forth between informal networks such as the extended family and formal networks such as limited liability companies. Fukuyama (2000) argues that cross-cultural variation in informal networks accounts for cross-national differences in the characteristic form of individual business

The logic of a "mixed society" (Rose, 1986) is that individuals and households are much more concerned with their total welfare than with its source. Many basic elements of welfare are the joint outcome of a multiplicity of resources. For example, health results from individual diet and exercise; informal support from friends and neighbors when feeling unwell; medical services for which payment may be made; and hospital care in a public institution. The specific network employed by a given individual can vary from situation to situation. In a modern society individuals may rely on the market for food but rely on informal social networks for their emotional wellbeing. To reduce the concept of social capital to a single type of network-whether informal non monetized. cooperation or formal organizations-forecloses understanding the variety of networks that individuals can have. 2 It also ignores a basic analytic question: to what extent and under what circumstances do individuals differ in their reliance on social capital networks for welfare? Concern with the organizational forms of collective action led Coleman (1990: 302) to define social capital in terms of networks that can be used as instruments for the production of goods and services. Coleman also emphasized that networks tend to be situational. Getting a pension involves interaction with officials in a large bureaucratic organization, where as organizing a social evening for a church depends on informal personal networks. Insofar as networks vary between situations, social capital cannot be reduced to a single unit of account that can be aggregated into a sum-mary statistic characterizing the whole of society. Nor can indi-viduals be characterized as having or not having community capitals of Brintik Hill Graveyard Communities . Natural Capital, Human capital, spiritual capital, intelectual capital, emotional capital, adversity capital, health capital economic capital, and Social Capital.

Therefore, when the individual's social capital is de-fined and measured in terms of social integration or generic sharing of social values such as" participation in the local community, pro-action in social context, feelings of trust and safety, neighbor-hood connections, connections with family and friends, tolerance of diversity, value of life and work connections" (Onyx and Bullen quoted in Wool Cock 
and Narayan 2000, p.241), it has only limited usefulness in analysis collective action between firms. A network analysis definition of social capital is equally unsatisfactory to analysis interfirm cooperation. Being at the centre of an articulated system of personal relationships can give significant economic advantages such as arbitrage, exploitation of information, etc. (Burt 1997) but it is difficult to see how numerical increase of the relationships in itself can solve the problems of cooperation. Collective action is in fact normally hampered rather than helped by increasing the number of participants.

The Brintik Hill Graveyard Communities has been successful employing this concept mostly because of the creativity of its people and their successbased attitude. "Improvise, Modify, Adapt, and Overcome"...This is the motto of the Brintik Hill Graveyard Communities. It comes in several forms; sometimes only three (removing Adapt, I think); sometimes rearranged. "Problem Solving: Improvise, Adapt, Overcome" Posted Tuesday, February 1, 2011 http://-www.peakprosperity.com/ blog/improviseadapt-overcome /52001 Using IMAO (Improvise, Modify, Adapt and Overcome.) as survival strategy, there are five cases of the people of Brintik Hill Graveyard Communities in Semarang has been successful, enhancing and survive. There are the cases breaking the vicious circles of economic and political poverty, the case of NGO's intervention, the case of government intervention, the case of helping with direct cash, and the case of values internalization.

\section{Conclutions}

An actual participation in local institutions, their use of services, and information that identifies the welfare level of households and their coping strategies. Their resources are so seriously below those commanded by the average individual or family that they are, in effect, excluded from the ordinary living patters, customs and activities. Breaking link of the vicious circles of economic and political poverty by using the social values, enhancing of adaptive capacity, and community capital of Brintik Hill Graveyard Communities.

Interventions may be enhancing their conditions. Government intervention and Non Government Organizations intervention could be used in cutting the vicious circles of economic and political poverty. Adaptive capacity in coupled social system ecosystem to result a model of survival strategy in historical sociology - ecology.

\section{Refferences}

Beach, King and Flavia Ramos. 2010. International Action Research in Education Workshop I. Semarang: Semarang State University

Fukuyama, Francis. 2000. The Great Disruption(Human Nature and The Reconstruction of Social Order). New York: Touchstone

Frank, Andre Gunder., 1967. Capitalism and Underdevelopment in Latin America: Historical Studies of Chile and Brazil, New York: Monthly Review Press.

Grootaert, Chriatiaan \& Thierry van Bastelaer (eds.). 2002. Undersatnding and Measuring Social Capital. A Multidiciplinary Tool for Practitioners. Washington DC.: The World Bank

Gracie M. Ochieng May 1998, Working papers no1

http://www.worldbank.org/socialdevelopmen t, Washington, DC :The World Bank. Social Development.

Locatelli, B., Kanninen M., Brockhaus M., ColferC.J.P., 2008a. Murdiyarso D., Santoso H., Facing an Uncertain Future: How Forests and People Can Adapt to Climate Change. Centre for International Forestry Research. Bogor

Locatelli, B., RojasV., SalinasZ.,2008b. Impacts of payments for environmental services on local development in northern Costa Rica: a fuzzy multicriteria analysis. ForestPolicy and Economics 10 (5): 275-285.)

Locatelli,B.,PramovaE., 2010, Forests and adaptation to climate change: what is at stake? World Resources Report 2010 Expert Perspectives. Question 4. (www.world resources report. org/ $\mathrm{nl} /$ responses forestsand adaptation- -change-what-stake-0)

Sunarjan, YYFR. 2014. Survival Strategy Komunitas Makam Gunung Brintik Semarang. Salatiga: Satya Wacana 


\section{University Press.}

Sylvia. Chant, 1994.Women, Work and Household Survival Strategies in Mexico, 1982-1992: Past Trends, Current Tendencies and Future Research. Bulletin of Latin American ResearchVol.13, No. 2 (May,
1994), pp. 203-233Published by: Blackwell Publishing Article Stable

URL: http://www.jstor.org/stable/ 3338275

Weston, Louise (ed). 1977. The Study of Society Second Edition. Connecticut:The Dushkin Publishing Group Inc. 